\title{
СОЦИОЛИНГВИСТИЧКЕ ОДЛИКЕ НАСЛОВА АМЕРИЧКИХ РЕКЛАМНИХ ИНТЕРНЕТ БИЛТЕНА
}

Рекламни сајтови се разликују по врсти производа које промовишу и по циљним групама које таргетирају, а циљ овог рада је да се исцртају профили оглашивача и начини убеђивања на основу корелације између социолингвистичких одлика наслова рекламних интернет билтена и ставова које аутори настоје да наметну потенцијалним потрошачима. Испитујући лексичке, граматичке и нарочито облике глаголске модалности, открили смо дистинктивне карактеристике наслова које одражавају природу савремених облика комуникације на енглеском језику.

Кључне речи: интернет, билтен, наслов, реклама, социолингвистика, модалност.

\section{1. Комуникациони процеси у савременим електронским медијима}

Комуникација је суштински процес размене (Томић 2004: 10), а њен идеални циљ би требало да буде формирање појединца кроз стицање сазнања о себи, свету и стварање могућности за повезано деловање људи (19). Основни предуслов друштвене комуникације јесте објективност важења материјалних знакова саопштавања, и ту лежи изазов могуће манипулације, будући да је још Аристотел тврдио да реторика не тежи изазивању рационалног одобравања, већ добијању емотивне сагласности (Еко 1973: 92-94). Новине и часописи су се развили као природни след других 
облика вербалне комуникације, а одликују их уска специјализованост обраде теме и моћ утицаја на читаоце (Berry 2008: 5). Масовни медији своју снагу темеље на механизмима памћења (Stephens 2007: 17), а селекција садржаја који се пласира успоставља нову реалност људи (Хабермас 2012: 187).

Медијум је порука која одређује природу знања епохе (McLuhan 1994: 7). Савремени електронски медији су постали средство корпорација које преко њих лако допиру до најшире публике, која је хетерогени колектив састављен на основу заједничког поља интересовања често пасивних индивидуа са којима се успоставља истовремени контакт (McQuail 1997: 54-55). Колдри (Couldry 2000: 54) препознаје да медијски процеси толико утичу на то како друштво разуме и опажа себе да се све појаве своде на ниво робе и персонализовани воајеризам, док Гамсон (1994: 191) примамљивост те робе види у рационалности која лежи иза модела које промовишу познате личности. Тејлор и Харис (Taylor, Harris 2008: 18-19) прихватају став Валтера Бењамина, који каже да се сваки медијум базира на традиционалном, али да ипак има своју префињену граматику којом се стварају псеудо-догађаји. Узимајући ово у обзир, циљ рада је да се социолингвистичком анализом наслова рекламних интернет билтена расветле начини сугерисања и уопштавања идеја које аутори настоје да промовишу или прикрију. Од 440 наслова који су сакупљени од 4. до 27. јуна 2017. године из америчких билтена Byrdie (даље: 5$),{ }^{1}$ Goop (I), MyDomaine (M), Stuart Weitzman (C), TheFashionSpot $(\Phi)$, Vogue(B) и WhoWhatWear $(W)$, издвојили смо 63 наслова. Услов одабира је био да наслови морају имати макар један модални глагол како бисмо подробније истражили понашање модалних глагола у промотивним порукама.

1 Интернет адресе коришћених сајтова наведене су у делу Извори $u$ литература. 


\section{2. Анализа социолингвистичких одлика наслова америчких рекламних интернет билтена}

Просечан број речи у $\Gamma$, Б и $M$ je 14, у $C$ je 11, у $\Phi$ је 9,6. Анализа $W$ нас доводи до звонасте криве са екстремним тачкама 7 и 32, где је врх код 11 са просечним бројем речи 12,63. Од просека видно одступа $B$ са екстремима у 8 и 26 и просеком од 16,63 речи. Забележени примери потврђују да је употреба великих почетних слова у писању лексичких речи стандард у енглеском језику осим у случајевима када у наслову преовладава наративни карактер уз примену више речи са јасним циљем убеђивања. Предлози се пишу великим почетним словом када се њихово значење опажа као кључно за поруку текста, као у From и Without и када се значење предлога преклапа са значењем прилога као у Outside.

Директност саопштавања се постиже изостављањем знака навода при цитирању и употребом кратких упитних реченица након изјавних реченица неутралног значења. Призвук искључивости саветодавног и заповедног тона доносе узвичне реченице попут You Can Thank Us Later! и императивне реченице које долазе после неке констатације и интерпункцијски се завршавају тачком, попут Stock Up. Наглашавање беспоговорности кулминацију има у одвојеном писању појединачних речи, као у примеру Must. Buy. Непосредност се остварује и елиптичним изостављањем као y ${ }^{\star}$ It Is) No Lie: Editors Will Never Wear.

Властите именице упућују на познате личности из света шоу-бизниса којима је додељена улога узора (Beyoncé и Jaden Smith), популарна дешавања (Tony Awards) и савремена средства комуникације (Amazon и Instagram). Тејлор и Харис (2008: 133; 157-158) уочавају тренд ширења култа особа које постају познатије захваљујући томе што су већ познате, тако да тривијализацијом узвишеног дражи егзотике постају доступне свима. Географске топониме, као што је име улице Abbot Kinney, назив града Venice и предела Arabian Peninsula, уочавамо у насловима В и Г, када се у дужем наративу нуде пре услуге него конкретни производи. Утисак је да се еклатантно рекламирање брендова узима као сувише нападно 
jep, осим примера Topshop, приметно је непомињање назива робних марки. Заједничке именице у насловима указују на оно што се продаје, али оне увек иду уз опис специфичности тог производа: These Comfortable Shoes, The 10 Swimsuits I Always Get Compliments On итд. Поред позивања на харизму познатих ради рекламирања, игра се на карту анонимног ауторитета када се користи облик попут A Stylist Told Us. Посеже се и за снагом личног обраћања уз употребу заменице I, као у I Always Get Compliments, заменицеwe5 пута, us 4 пута и присвојног детерминатора our само једном у Our Closets. Лично обраћање је својствено овим насловима, што

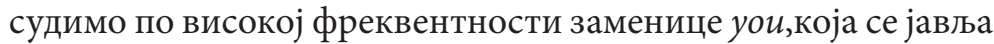
чак 34 пута, и присвојног детерминаторауоur 7 пута, као у Consider Us Your Personal Shopper.

Девелот (Develotte 2016) говори о начинима постизања боље памтљивости текста кроз алитерацију, а њу бележимо у People Will Wonder Where. Римовање у I Can't Quit Buying..., So I Stopped Trying такође помаже да се текст лакше меморише. Ђорђевић (1997: 98) аспект понављања види у употреби неодређене заменице Опекао супститута за именицу, као у You Don't Have To Be Related To a Royal To Dress Like One. Ђорђевић (92-93) описује назнаке двосмислености у понављању које долазе до изражаја у правој заменичкој употреби облика it у анафори коју можемо схватити као именичку или клаузалну у случају There's no denying rosémania has become overwhelming. But, it begs the inevitable question: Can it last? Примена неодређености омогућава да се износе дискутабилни ставови: она се исказује и преко anyone у Anyone Would Want to Copy, а упечатљиво је да either y Would You Ever Get Dressed Without Accessorizing? We Wouldn't Either посредно наводи на заузимање одређеног гледишта. Општи заменички облици доприносе зумирању пажње и уопштавању (151), попут every у Every Woman Should Own, everyone у Everyone Will Be Talking About и честе примене all, као у You'll Want to Know All About. Једини одрични заменички облик no one показује да се одрицање постојања или присуства ентитета не сматра погодним инструментом промовисања.

This ce налази на 4 места у функцији заменице, а на 10 места у својству показног детерминатора где позива на 
блискост са наредном именицом типа Piece и Season, док These има улогу заменице и показног детерминатора уз бројиве именице у множини. Само у једном примеру имамо облик those у функцији показне заменице. Облик that је забележен у пет случајева као односна заменица којом почиње релативна клауза. Осим заменице who, која се јавља само једном у рестриктивној адјективалној клаузи, упечатљиво је одсуство релативних заменица иако су присутни where и when jep ce губи смисао њиховим изузећем.

Чланови се обично изостављају у новинским насловима (Swan 2002: 70), али овде се the јавља чак 29 пута, a 11 пута и једном an. Одређени члан најчешће фигурира испред именице описане речима у адјективалној функцији, као у the New Red. Неодређени члан се углавном користи уз именице у једнини у копулативним конструкцијама дескриптивне улоге (Ђорђевић 1997: 191), мада у That Can Be Worn a Dozen-Plus Ways неодређени члан се јавља уз именицу у форми множине, али у значењу једнине. Повећану учесталост чланова објашњавамо тиме што су ови наслови експликативног карактера - пре их тумачимо као део реченице, а не синтагме.

Пажња читалаца се привлачи језичком економичношћу и креативношћу аутора, које налазимо у творби полусложеница у улози придева или именице. Комбинују се именица и прошли партицип у hand-rolled, док у Low-Cost и Low-Key придев low испред именице има значење редуковане релативне клаузе. У осам $(66,67 \%)$ сложеница присутан је неки предлог (Under-the-Radar и Spin-Off), а запажена је употреба облика множине у полусложеницама као Heels-with-Jeans и Cover-Ups.

Примена бројева ствара утисак егзактности и проверљивости. То је случај са навођењем година у This Throwback '90s Top, цена као у the \$37 Version и редоследа у The \#1 Way to Wear. Међутим, бројеви су најприсутнији при истицању броја опција за одабир: у 9 примера распон иде од 3 до 30, a најчешће се јавља понуда од 8 елемената (8 Fresh Outfits). Неодређени квантитет се може исказати нумеричким квантификаторима (263-264), а они готово да нису заступљени осим many у So Many Compliments и облика dozen-plus у Dozen-Plus Ways. 
Судећи по избору лексичких речи, увиђамо да је у праву Анг (1985) када тврди да се задовољство потрошача изводи из фиктивне природе решења наметнутог проблема,будући да се аутори наслова постављају у позицију онога ко боље зна и ко чак провоцира осећање несигурности код читалаца како би им се понудиле солуције за излаз из зоне неугодности. Креира се импресија да будућа муштерија може да набави нешто проверено што има Over 6100 Great Reviews on Amazon, поуздано као у One Constant You Can Rely On и нешто што није шкодљиво, као у ... Won't Ruin Your Life. Пласира се оно што ће особу учинити примећеном као у 8 Fresh Outfits That Will Get You 100\% Noticed. Нуди се производ који ће потрошачу обезбедити актуелност и популарност преко То Кеер You Informed, We'll Be Updating the List и Looks Everyone Will Be Talking About. Потенцира се неизбежност кроз the inevitable question и Style You Couldn't Avoid This Season, неизвесност којом треба овладати у the Unexpected Mascara Color, а нелагодност се незрело превазилази тако што треба друге заразити њоме као у People Will Wonder Where You Found These.

Алудира се на актуелна друштвено-културна дешавања као што су збивања у британској краљевској породици и Met Gala, а фаворизовање такмичарског духа и свести о могућности промене социјалног статуса откривамо у промовисању телевизијског програма Bachelor Spin-Off и преноса 2017 Tony Awards. Намећу се обрасци понашања и активности који подстичу осећај припадања слоју урбаних људи који прате одређене трендове - људи који путују на сличан начин, слушају популарну музику, носе препоручену одећу и обућу, а игру речи имамо у Could Orange Also Be the New Red, где се алудира на актуелну серију Orange Is the New Black, у којој се прати сналажљивост жена у незавидним животним околностима.

Упечатљиво је одсуство сложених прошлих времена, док се претерит јавља код глагола found, offered, told, stopped и gave. Овим глаголима је заједничко то што им је дужина до два слога и што су транзитивни, па фигурирају као најава остатка фразе. Садашње трајно време заступљено је само у једном наслову, а највећу заступљеност има садашње просто 
време са 19 примера, од којих 9 случајева јесте неки облик копулативног глагола to be. Овде се јавља глагол sound, који Ђорђевић (1997: 326) назива „квази-копулативним” јер, као што је овде случај, може бити синониман са копулом to be. Сви остали глаголи у садашњем простом времену су прелазни и не дужи од два слога (Begs, Refuse, Shares). Садашњи прости и трајни перфекат користи једино В када у дужим насловима доминира приповедачки тон. Забележена је једна условна зависна реченица другог типа, тако да можемо рећи да кондиционалне клаузе нису метод исказивања поруке у насловима билтена.

\section{1. Анализа употребе динамичке,} деонтичке и епистемичке модалности

Модалност је прикладна за усмеравање пажње читалаца, узимајући у обзир да Бајбијева (Вуbee 1994: 176-177) модалношћу сматра све што говорник може да чини са пропозицијом. Палмер (1979: 3-4) разликује три типа модалности: динамичку, деонтичку и епистемичку модалност. Динамичка модалност се повезује са способношћу и са диспозицијом, она сугерише постојање околности у стварном свету које чине могућим или нужним остварење неког догађаја, а деонтичком модалношћу говорник перформативно ствара могућност, допуштање, обавезу или забрану да се нешто оствари (39). Фроли (Frawley 1992: 407) описује епистемичку модалност као ону која се бави релативизованом истином да би се исказали посредно закључивање, мишљење, уверење, нагађање и сумња.

\subsection{1. Динамичка модалност}

Неутрални тон поруке налазимо у саопштавању да је неки догађај могућ. У случају The One T-Shirt You Can Wear With Everything You Own видимо потврду за Палмеров (1979: 71-74) став да се неутралност појачава уз безлични субјекат you, а у примеру Accessory That Can Be Worn поткрепљујемо Палмера (87-88) када каже да и пасивно стање истиче 
неутралност.

Савременом човеку није лако да се докаже у свету немилосрдне конкуренције, па не чуди што се људи из маркетинга окрећу сугестивности (74), јачању представе код потрошача о личној моћи. Глагол CAN је погодан за ту намену зато што CAN директно или посредно упућује на способност субјекта (Ehrman 1966: 13). Fashion Items That Can Age You показује да оријентисаност према субјекту може бити усмерена и ка нечему неживом када се истиче моћ да се узрокује неко дешавање. На три места јављају се одрични облици уз CAN којима се имплицира да се нешто не дешава, док динамичко MUST у насловима оставља траг неупитности ауторитета који прокламује оно што се рекламира. HAVE (GOT) TO чини израз обавезе наметнуте од стране спољашњих околности у смислу „BE OBLIGED TO” (Palmer 1979: 92). Ако зависност од околности тумачимо као сопствену немоћ, показатељ да то није став пожељан за пропагирање детектујемо у You Don't Have To Be Related To a Royal To Dress Like One- једином наслову који садржи HAVE TO, али и он је у облику негације којом се пориче везаност за околности.

\subsection{2. Деонтичка модалност}

Инсистирајући на континуитету градијентности, Свитсерова (Sweetser 1990: 9) у маниру когнитивне семантике метафоричким мапирањем увиђа јединственост семантичке основе модалности, премда и Палмер (1979: 58) у термину „коренске модалности” избегава разграничавање између динамичке и деонтичке модалности. Ову нејасноћу класификовања налазимо у пет наслова који садрже глагол CAN, који може бити протумачен у смислу динамичке способности, али их подводимо под деонтичку могућност зато што је снажнији осећај да аутори наступају са места моћи прописујући шта је дозвољено или како би когнитивни семантичари интерпретирали - делају као претпостављене фигуре ауторитета које уклањају препреку на путу да се нешто оствари. CAN може да преноси неку наредбу уз примесе одсечне неучтивости (60): такву гордост у You Can Thank Us 
Later! разумемо као одјек тежње за непосредношћу и присношћy. У Items Every Woman Should Own глагол SHOULD носи значење BE SUPPOSED TO и има смисао препоруке.

\subsection{3. Епистемичка модалност}

Упадљива је опредељеност да се истакне интензитет онога што се дешава или тек треба да се деси. Типични представник епистемичке могућности је глагол MAY, који у комбинацији са инфинитивом презента упућује на садашњи и будући догађај, док се у Endless Stream of News May Be Confusing трајање радње наглашава прогресивним инфинитивом. Иако MIGHT указује на смањени степен извесности обистињења садржаја пропозиције у односу на МАY, једнак је удео $(3,17 \%)$ употребе ова два глагола. Инфинитивом перфекта уз МАY доноси се епистемички суд о догађају из прошлости о коме говорник не поседује тачно знање, што је погодан начин на који се аутори ограђују од веродостојности предоченог (80). Спекулације и извођење закључака обликују илузију удаљености, стога у овом смеру иде анализа It Could Be the Opening Plot to a Movie где је COULD дистални модал који јасније маркира епистемичку дистанцу у односу на ону исказану глаголом CAN (Трбојевић 2004: 77). Претпостављамо да негације модала MAY, MIGHT и COULD нема у примерима јер је концепт наслова такав да се иде у смеру оснаживања читаоца тиме што му се нуде, а не ускраћују опције. Пример She Is So Stunning, She Cannot Be Real показује да се негација епистемичког MUST не врши преко облика MUSTN'T, који повлачи деонтичко тумачење, већ помоћу CAN'T или CANNOT (82). SHOULD уз инфинитив презента стоји на граници између деонтичке и епистемичке употребе, али се зато испред инфинитива перфекта у We Should Have Seen This Coming изриче строг суд о прошлом догађају.

Потврду да наслови треба да подстичу представе о ономе што долази запажамо у чињеници да је глагол WILL, ca 23 примера, најзаступљенији када изражава епистемичку модалност са предиктивним значењем будућности (Трбојевић 2004: 85). Предиктивност се појачава 
комбиновањем са прогресивним инфинитивом презента, али и прилозима PROBABLY и TOTALLY у дедуктивним фразама које Лајонс (Lyons 1977: 807) назива „модално хармоничним". Тентативним WOULD истиче се мања поузданост суда (Palmer 1979: 48), овим обликом се пласира осећај неодређености и слободе избора, што је опција за коју се аутори далеко ређе одлучују у односу на WILL.

\section{3. Профили оглашивача на основу анализе садржаја наслова америчких рекламних интернет билтена}

Оглашивачи се разликују по профилу промовисаног садржаја. $C$ рекламира искључиво обућу, без позивања на друштвени статус који ова обућа може конотирати. У насловима $C$-а, који се непретенциозно тржишту сваког другог дана представља кратким описима изгледа и намене актуелних колекција обуће, тек се на једном месту јавља епистемичко WILL. Иако су им заштитна лица младе девојке попут Вилоу Смит и Кендал Џенер из медијски познатих породица, које одликује упечатљива социјална различитост у односу на већину популације и које се само сликају без икаквог коментарисања обуће, њихова имена се не помињу у насловима билтена. Непомињање имена промотерки у насловима привидно умањује њихову вредност спрам робе која се рекламира, ове личности су дистракција и антитеза перципираног мањка (Rojek 2001: 90).

$5, M, \Phi$ и $W$ настоје да рекламирају модне предмете који подразумевају поистовећивање са животним стилом урбаних активних жена средње и више средње класе. Будући да $Б$ за циљну групу има млађу популацију, појаву само једног епистемичког WILL доживљавамо као процену оглашивача да млађе жене немају потребу да им се подилази указивањем на то да баратају довољном количином информација за доношење судова - ова публика се вероватно поима као спремна да некритички прихвата савете који нуде могућност припадања некој друштвеној групи. Употребом садашњих времена 
и императива, облицима exclusively, only, the first и there's nothing quite, аутори позивају да се пазари или примени оно што по њима решава исконструисани проблем и обећава надмоћ у групи.

Мтематски покрива и област уређења животног простора, при чему се фаворизује еклектични стил којим оглашивачи показују да свако већ има нешто што је потребно да би се било у тренду, али да се и то може допунити нечим бољим. $M$ долази из исте редакције као и 5 , намењен је истој публици и отуд не изненађује што $M$ има употребљена само два модална глагола код којих уочавамо скоро потпуно одсуство примене епистемичке модалности која наговештава различите варијанте закључивања. Аутори наступају из угла супериорности, делећи лекције кроз које сугеришу да је њихов начин једини или најбољи, а то потврђују фразама у којима доминирају садашња времена, императив и придевска употреба инфинитива презента.

$B$ пропагира свет забаве и славних личности изразито либералних схватања, које се не устручавају да се позивају и на своју политичку припадност. Часопис тежи да успоставља трендове који делују слободоумно. Софистицираност оваквог прилаза се код модалних глагола огледа у одсуству деонтичке нужности, а деонтичка могућност је једино у два случаја заступљена преко глагола CAN и SHOULD. Међутим, вероватно у настојању да делују објективно, аутори су склони да се определе за CAN код кога преовладава оријентисаност према дискурсу у значењу динамичке могућности. Жеља да се читаоцу прикаже посвећеност сакупљању мноштва детаља ради стицања бољег, предрасудама неоптерећеног, увида при што рационалнијем закључивању рефлектује се кроз дуге наслове који су неретко у форми питања у којима доминира епистемички тип модалности. Наслови доносе неке нове детаље о познатим особама или актуелним феноменима шоу-бизниса, па ова префињеност понекад не дозвољава да се лако закључи шта они заправо продају. Глаголски облици су сведени на доминантно садашње просто време, нешто ређе претерит и императив. Да се уочити шаблон наслова у коме преовлађују речи до три слога 
и именичке фразе. Креирају се текстови и наслови за предузимљиву, скоро бескрупулозну публику којој се децидираним коментарима изгледа и поступака успешних људи ствара привид да може бити на „ти” са најмоћнијим људима из естрадног миљеа.

$\Phi$ је сајт који одликују оштре опаске на рачун актуелних појава које се граниче са изјавама личног свиђања или несвиђања. Сајт је осмишљен као $B$ за млађу публику, али је стил овог сајта нешто неодмеренијег израза, следствено томе не чуди што за потенцирање својих ставова користе једино епистемичку модалност: само у једном случају МАY наговештава могућност, док је у преостала четири случаја уз помоћ CANNOT негирана нужност, уз SHOULD је исказана јака убеђеност у значење пропозиције, а уз WILL је епистемичка нужност представљена кроз предиктивно наглашавање будућности. Ово је једини сајт који своју аутентичност перманентно гради на подривању онога шта конкуренти популаризују како би истакли свој избор. Искључивост је апострофирана у фреквентном посезању за суперлативом придева и бомбастичним изразима као што су so stunning и seriously unique.

Уредници сајта Wтеже да искомбинују оријентацију благо арогантне острашћености часописа $B$ са лепршавим, на први поглед ненаметљивим ставом сајта 5 . Wодлази најдаље у потреби да постигне ефектност на најразличитије начине. Употребом динамичких глагола CAN и дисталног облика COULD за могућност, као и глагола MUST за нужност, као да се истиче непобитност природности става којим се читаоцу не оставља простор да се успротиви. Глаголи CAN и SHOULD у значењу деонтичке могућности бивају искоришћени да се покаже давање дозволе да се нешто уради, при чему до изражаја долази својство глагола деонтичке могућности да звуче прилично дрско у тежњи аутора да буду судије укуса. Епистемичка могућност је исказана само на једном месту преко глагола COULD, али је зато епистемичка нужност предиктивне улоге глагола WILL оно што је присутније од свих других типова модалности у насловима рекламних билтена. Заповедни наступ се истиче императивом, лексичким 
избором глагола одбијања у I Refuse, суперлативом придева, редним бројем у The \#1 Way, а одјек ригидности назиремо у прилозима Always, Everywhere и општим заменичким облицима.

Сведеност и инсистирање на ненаметљивој природности је оно на чему Г заснива свој имиџ. Нема директног наметања надређеног ауторитета, па је за очекивати и било да не наиђемо ни на један случај деонтичке модалности, а нема ни одрећености става говорника према истинитости пропозиције, што је класично логичко одређење епистемичке модалности. Привидна неутралност као принцип промовисања види се у три пронађена примера динамичке модалности у којима је акценат на способности и диспозицији субјекта да нешто реализује, као у случају употребе глагола CAN. $Г$ нуди обећања удобности животног стила виших друштвених слојева, неретко пласирајући прескупе производе и услуге. Потенцијалним клијентима се подилази рекламирањем конкретних артикала на крају мејла, за разлику од наслова који промовишу промену животног стила, освешћено бављење собом и својим окружењем. Константно пропагирају нове приступе стандардним рутинама људи, што остварују дужим насловима приповедачког тона, а језички то се огледа у учесталој креацији полусложеница наликLow-Waste-Water Denim.

\section{4. Закључак}

Савремено доба одликује изобиље информација, робе, услуга, и изазов је направити ваљане изборе. Оглашивачи морају да изграде јасну представу о томе шта производ који промовишу може учинити примамљивим, па тако и састављачи рекламних интернет билтена тајмингом слања и селекцијом речи и фраза у насловима билтена показују на који начин опажају потенцијалног купца, које вредности се одређују као прихватљиве и шта се сматра непожељним. Све се своди на поигравање базичном жељом човека да буде прихваћен и вољен. Наслови се састављају тако да се доследним профилом билтена формирају очекивања 
могућих муштерија који пристају на причу у којој се прво креирају потребе, а нешто касније нуде предлози превазилажења истих.

Наслови имају просечан број речи од 9 до 16, чиме се избегава замка питања двосмислености услед премалог броја речи, али се избегава и замка преопширности текста и губитка заинтересованости читалаца. Читалац се тако осећа довољно вредним и испоштованим, јер тај број речи јесте ниво реченице која нуди представу о поседовању заокружене мисли. У прилог тврдњи да ови наслови више имају особине реченице него синтагме сведочи и веће присуство одређеног члана у овим насловима него у новинским насловима који махом имају облик синтагме и за које је стандардно одсуство члана the. Боља разумљивост поруке се постиже употребом речи малог броја слогова, а посебно фреквентних једносложних и двосложних глагола у претериту. Сви оглашивачи великим почетним словима проминентним местом, изостављањем и комбинацијама речи у наслову истичу најбитније сегменте порука, које се моделују према процењеном профилу циљне групе. Аутори наслова сајтова намењених популацији млађих урбаних жена рачунају да су читатељке спремне да се повинују ауторитативном гласу који учесталом употребом облика people, every, all, the only, inevitable и суперлатива придева сугерише једнообразност мишљења. Обраћање у садашњем времену и честа употреба динамичког глагола CAN и епистемичког WILL појачавају импресију укључености у актуелна дешавања и дају наду да су промене оствариве, док наредбодавни тон императива и глагола MUST не уноси страх због природе комуникације преко интернета, која не обавезује да се по аутоматизму одговори на захтев. У тој споразумној дозволи да се реципијент без последица може понашати хировито попут размаженог детета које се увек може вратити у окриље фигуре у супериорном положају лежи драж свих интеракција на интернету. Илузија разумевања од стране аутора билтена креира се и писањем о познатим личностима у контекстима у којима се читаоци могу идентификовати са њима, али на граници непоштења је непомињање неопходног одрицања 
и цене славе који прате свет познатих. Билтени сајтова намењених искуснијој публици претендују на то да укажу да се рачуна на њихову моћ расуђивања, сервирају им се опције ради усмереног закључивања, али су и овде теме исплетене око детињастих снова: фокус је на што безболнијем успостављању жељене хармоније. Ставови се подупиру употребом суперлатива, термина искључивости и наговештавањем могућности поседовања важних информација које ће гарантовати престиж.

По насловима америчких рекламних интернет билтена видимо да они могу бити просветитељи новог доба нудећи савете о пожељним животним навикама, али остаје могућност да њихов стил временом може постати заморан и фрустрирајући када услед отрежњујућег сусрета са реалношћу читалац схвати да се аутори мање или више поигравају људским комплексом инфериорности пласирајући недостижност, површне и делом извитоперене вредности.

\section{Извори и литература}

Ang, Ien. Watching 'Dallas'. London: Methuen, 1985. Штампано.

Berry, David.Journalism, Ethics and Society. Burlington: Ashgate, 2008. Штампано.

Bybee, Joan. et al. The Evolution of Grammar. Chicago/London: The University of ChicagoPress, 1994. Штампано.

Couldry, Nick.The Place of Media Power. London: Routledge, 2000. Штампано.

Develotte, Christine. et al.Discourse analysis of newspaper headlines. http://wjfms.ncl.ac.uk/titles.htm, 2016. Veb. 24. 11. 2016.

Ђорђевић, Радмила. Грамайика енілееской језика. (2. изд.). Београд:

Чигоја штампа,1997. Штампано.

Ehrman, Madeline.Elizabeth. The meanings of the modals in present-day English. TheHague: Mouton and Co., 1966. Штампано.

Еко, Умберто. Кулитура, информачија, комуникација. Београд: Нолит, 1973. Штампано.

Frawley, William. Linguistic Semantics. New Jersey: Lawrence Erlbaum Associates, Inc, 1992. Штампано.

Gamson, Joshua.Claims to Fame: Celebrity in Contemporary America. 
Berkeley, CA:University of California Press, 1994. Штампано.

Хабермас, Јирген. Јавно мъенье. Нови Сад: Mediterran Publishing, 2012. Штампано.

Lyons, John.Semantics - Volume 2. London/New York: CUP, 1977. Штампано.

McLuhan, Marshall. Understanding Media. Cambridge: The MIT Press, 1994.Штампано.

McQuail, Denis. Audience Analysis. London: Sage Publications, 1997. Штампано.

Palmer, Frank Robert. Modality and the English Modals. London/New York: Longman,1979. Штампано.

Rojek, Chris. Celebrity. London: Reaktion Books, 2001. Штампано.

Stephens, Mitchell.A History of News. (2. izd.). New York: OUP, 2007. Штампано

Swan, Michael. Practical English Usage. (2. izd.). New York: OUP, 2002. Штампано

Sweetser, Eve. From Etymology to Pragmatics. Cambridge: CUP, 1990. Штампано.

Taylor, Paul A., Harris, Jan.L.I. Critical Theories of Mass Media: Then and Now.Maidenhead: McGraw-HillEducation, 2008. Штампано

Томић, Зорица. Комуникација и јавности. Београд: Чигоја штампа, 2004. Штампано.

Трбојевић-Милошевић, Ивана. Моgалносӣ, суg, исказ. Београд: Чигоја штампа,2004. Штампано.

Интернет извори у периоду од 4. јуна до 27. јуна 2017. године:

goop@e.goop.com

mail@email.thefashionspot.com

newsletter@whowwhatwear.com

newsletter@mydomaine.com

newsletter@byrdie.com

vogue@mail.vogue.com

weitzman_wire@stuartweitzman.com 


\title{
Sanja Korićanac
}

\author{
SOCIOLINGUISTIC FEATURES OF AMERICAN \\ COMMERCIAL INTERNET NEWSLETTER TITLES
}

\begin{abstract}
The aim of this paper is to present the basic sociolinguistic characteristics of commercial newsletter titles sent via e-mail. We have examined the titles coming from the following sites: Byrdie, My Domaine, Who What Wear, Stuart Weitzman, The Fashion Spot, Vogue and Goop. These sites differ by their product type and customer target groups. It has been established that the advertiser profile is possible to be delineated according to the correlation between sociolinguistic title features and the messages the authors aim to convey to their customers-to-be. The authors have been proven to take great care of word number, punctuation and specific capital letter usage. The choice of Proper Nouns clearly displays which celebrities, places and events are imposed as prestigious, while Common Nouns, Universal Pronouns, Indefinite Pronouns and Determiners are employed to indicate the generic nature of their views. The Superlative form of Adjectives appears so as to support exclusive claims. Though Definite Article omission is conventional in newspaper titles, that is not the case in these Internet newsletter titles.

Having analyzed the verb forms in particular, we came to the conclusion that Present Simple Tense and Imperative prevail and that negative forms are quite rare. Special attention has been paid to the interpretation of dynamic, deontic and epistemic usage of Modal Verbs. Modal Verbs combined with their propositions denoting future events are confirmed to be the most frequent of all Modals.
\end{abstract}

Key Words: internet, newsletter, headline, advertisement, sociolinguistics, modality. 